\title{
PENGEMBANGAN VIRTUAL LABORATORY BERBASIS ANDROID PADA MATA PELAJARAN BIOLOGI DI SMAN 1 ABUNG SEMULI LAMPUNG UTARA
}

\author{
Mirawati, Zulfani Sesmiarni, Supratman Zakir, Iswantir \\ Program Studi Pendidikan Teknik Informatika dan Komputer, Institut Agama Islam Negeri(IAIN) Bukittinggi \\ Jl. Gurun Aur Kubang Putih Kab. Agam - Sumatera Barat \\ mirawaty353@gmail.com, zulfanisesmiarni@iainbukittinggi.ac.id, \\ supratman@iainbukittinggi.ac.id, iswantireiainbukittinggi.ac.id
}

\begin{abstract}
Biology learning on material that contains abstract concepts with high competency demands that require a scientific process / hands-on experience such as practicum to concretize and fulfill it is not optimally fulfilled due to limitations of space, time, activity, sensory power, and facilities, especially currently there is an adjustment in learning due to The Covid 19 pandemic. This study aims to develop an Interactive Learning Media, namely a Virtual Laboratory in .Apk format that can run on Android Smartphones that are valid, practical, and effective in supporting the learning of Biology material on the Food Digestive System class XI MIPA at SMAN 1 Abung Semuli, North Lampung. This study uses the 4D Thiagarajan Research and Development (R\&D) method combined with the Luther-Sutopo Multimedia Development Life Cycle (MDLC) Development Model. Through the research stages, a $13 \mathrm{Mb}$.apk was generated containing the Intro, Home, Instructions, Developer, KD/Objectives, Materials, Practicum, and Exercise pages. Based on the analysis of the Test Result Data to Experts and Users, the Application is declared Valid, Practical, and Effectively used by Biology Teachers and Students of class XI MIPA in supporting Biology learning materials for the Food Digestive System. With a validity value of 0.85 in the valid criteria, practicality 0.94 in the very practical criteria, the effectiveness value is 94.46 in the very effective criteria.
\end{abstract}

Keywords - Biology Learning Media, Virtual Laboratory, .Apk, and Class XI.

\begin{abstract}
Abstrak - Pembelajaran biologi pada materi yang memuat konsep abstrak dengan tuntutan kompetensi tinggi yang membutuhkan proses sains/pengalaman langsung seperti praktikum untuk menkonkretkan dan memenuhinya kurang optimal terpenuhi akibat keterbatasan ruang, waktu, aktivitas, daya indera, maupun fasilitas, terlebih saat ini tengah terjadi penyesuaian pembelajaran akibat Pandemi Covid 19. Penelitian ini bertujuan untuk mengembangkan sebuah Media Pembelajaran Interaktif yaitu Virtual Laboratory berformat.Apk yang dapat berjalan pada Smartphone Android yang valid, praktis, dan efektif menunjang pembelajaran Biologi materi Sistem pencernaan Makanan kelas XI MIPA di SMAN 1 Abung Semuli Lampung Utara. Penelitian ini menggunakan Metode Research and Development $(R \& D)$ model 4D Thiagarajan kombinasi Model Pengembangan Multimedia Development Life Cycle (MDLC) Luther-Sutopo. Melalui tahapan penelitian dihasilkan .Apk berukuran 13 Mb berisi halaman Intro, Home, Petunjuk, Pengembang, KD/Tujuan, Materi, Praktikum, dan Latihan. Berdasarkan analisa Data Hasil Uji Coba kepada Ahli dan Pengguna, Aplikasi dinyatakan Valid, Praktis, dan Efektif digunakan Guru Biologi dan Siswa kelas XI MIPA dalam menunjang pembelajaran Biologi materi Sistem pencernaan Makanan. Dengan Nilai Validitas 0,85 dalam kriteria Valid, Praktikalitas 0,94 dalam kriteria Sangat Praktis, Nilai Efektifitas 94,46 dalam kriteria Sangat Efektif.
\end{abstract}

Kata Kunci - Media Pembelajaran Biologi, Virtual Laboratory, .Apk, dan Kelas XI.

\section{PENDAHULUAN}

Perkembangan Teknologi mendorong upaya pembaharuan dan pemanfaatan hasil Inovasi Teknologi dalam proses pembelajaran[1]. Menurut Permendiknas No. 16 tahun 2007, dalam pembelajaran Guru dituntut mampu menganalisis kebutuhan, merancang, mendesain, menemukan, dan memproduksi dan menggunakan berbagai jenis sumber belajar diwujudkan dalam media pembelajaran berbasis teknologi dan informasi[2].

Namun yang terjadi saat ini, inovasi media pembelajaran berbasis teknologi secara khusus untuk menunjang pembelajaran minim dilakukan. Berdasarkan Observasi, wawancara Guru, dan penyebaran angket analisa permasalahan kepada Siswa kelas XI MIPA di SMAN 1 Abung Semuli Lampung Utara didapat bahwa Teknologi hanya digunakan untuk media sekunder (Classroom dan WhatsApp) dan mencari media utama (video), tidak digunakan untuk mengembangkan atau menginovasikan Media utama yang fungsinya untuk Siswa memahami materi ditengah keterbatasan pelaksanaan pembelajaran daring dan tatap muka saat Pandemi Covid-19, padahal terdapat materi-materi yang mengandung keabstrakan yang perlu dikonkretkan yang tidak bisa didapat dari membaca saja, yang seharusnya bisa diakali dengan perkembangan teknologi.

Mata Pelajaran Biologi adalah salah satu mata pelajaran inti program studi MIPA, memiliki rerata nilai 
raport semester 1 rendah di kelas XI MIPA, di dalamnya memuat konsep ilmiah bersifat abstrak dengan kompetensi tinggi yang pemenuhannya membutuhkan proses ilmiah (pengamatan langsung, praktikum, simulasi)[3] untuk menkonkretkan konsep sehingga siswa paham mendalam tidak sekadar tahu. Salah satu materi pada Mata Pelajaran Biologi adalah Sistem Pencernaan Makanan yang memuat proses didalam tubuh dan memerlukan Praktikum Uji Makanan di Laboratorium yang pelaksanaannya dapat terkendala akibat keterbatasan waktu, fasilitas, maupun ruang dan aktivitas yang terjadi saat ini akibat Pandemi Covid-19. Kegiatan yang berdurasi lama dan membutuhkan interaksi fisik seperti praktikum ditiadakan atau dipangkas waktunya, padahal dapat diupayakan terpenuhi dengan berbantuan teknologi.

Teknologi yang dimanfaatkan dengan optimal dalam inovasi media pembelajaran mampu mengatasi keterbatasan-keterbatasan yang muncul dalam pembelajaran terkait ruang, waktu, fasilitas, keabstrakan konsep, daya indra dalam memahami materi, minat, maupun motivasi belajar siswa[4]. Menurut Edgar Dale, semakin suatu objek atau materi disajikan dengan media bersifat nyata atau mendekati Real Object dan menjauhi verbalisme maka semakin besar hasil belajar/pengalaman siswa sehingga semakin paham[5]. Teknologi untuk mengatasi permasalahan diatas salah satunya yaitu konten berbentuk Multimedia Interaktif yang dapat dimanipulasi mendekati Real Object seperti Virtual Laboratory, dikembangkan menggunakan Aplikasi Komputer Adobe Animate CC dan Adobe Ilustrator menjadi Aplikasi Android, dengan perangkat akses berupa Smartphone Android sebagai perangkat yang dominan dimiliki Siswa dan menjalankan konten, yang dapat memudahkan Guru mengadakan pembelajaran, memudahkan Siswa menkonkretkan pemahaman dalam keterbatasan pembelajaran. Diharapkan Media yang dihasilkan Valid, Praktis, dan Efektif digunakan dalam Pembelajaran. Penelitian sebelumnya menyatakan Multimedia Interatif , Virtual Laboratory, dan Media beberbasis Android layak digunakan dalam pembelajaran. Sehingga Peneliti tertarik mengambil Judul Penelitian "Pengembangan Virtual Laboratory Berbasis Android Pada Mata Pelajaran Biologi di SMAN 1 Abung Semuli Lampung Utara".

\section{A. Media Pembelajaran}

Media Pembelajaran merupakan Perantara untuk menyampaikan pesan atau informasi pembelajaran yang dituangkan dalam simbol komunikasi verbal / non verbal kepada Siswa untuk dapat dipahami siswa sehingga memperoleh kesamaan makna berimplikasi pada tercapainya tujuan pembelajaran yang diharapkan[1]. Media / Perantara berupa alat dan pesan yang dimuatkan(konten). Baik Alat maupun Konten erat kaitannya dengan Teknologi, untuk pembelajaran yang inovatif, fleksibel, dan menjangkau fungsi kompleks.

\section{B. Multimedia Interaktif}

Multimedia Interaktif termasuk Media berbasis Teknologi. Multimedia Interaktif merupakan penyampaian informasi dengan menggabungkan beberapa simbol komunikasi(teks, audio, video, grafik) dan interaktivitas sekaligus yang diprogramkan oleh teknologi Komputer[4]. Multimedia Interaktif mampu membuat pengguna berkomunikasi dan berinteraksi dengan informasi yang diperlukan didalamnya melalui sistem navigasi yang logis[6]. Produk Multimedia Interaktif dapat berupa Model Tutorial, Game, Simulasi, atau Campuran (Hybrid) yang digunakan dalam kebutuhan sosial, budaya, ekonomi, maupun pendidikan.

\section{Virtual Laboratory}

Virtual Laboratory termasuk konten bagian dari Multimedia Interaktif yang mengusung model simulasi, yang dapat diterapkan dalam Dunia Pendidikan. Virtual Laboratory merupakan media yang dapat mensimulasikan kegiatan praktikum seolah pengguna berada pada laboratorium yang sebenarnya[3]. Model ini dapat mengatasi keterbatasan dalam pelaksanaan secara nyata dilapangan, seperti keterbatasan waktu, fasilitas, ruang, biaya, daya indra, dan ukuran, serta meminimalisir resiko kecelakaan praktikum. Dalam pembelajaran, materi yang perlu dipraktekan namun terkendala dapat diatasi. Serta Media ini mampu menarik perhatian, memotivasi[3], dan memberi kesempatan Siswa menemukan pengalamannya sendiri tidak terbatas di dalam kelas[7].

\section{Aplikasi Android (Apk.)}

Android bersifat Open Source sehingga banyak teknologi yang kita jumpai saat ini yang memfasilitasi pembuatan perangkat lunak yang dapat berjalan didalamnya(Aplikasi Android), yang mengkompilasi bahasa pemrograman bersama-sama dengan data dan file resources yang dibutuhkan menjadi paket android, sebuah file yang ditandai dengan suffix Apk[14]. File .Apk tersebut didistribusikan dan di instal pada perangkat Android, seperti Perangkat Smartphone yang dominan dimiliki Individu saat ini. Smartphone dapat digunakan sebagai alat akses dan menjalankan konten pembelajaran dalam bentuk Apk, dan .Apk dapat diprogramkan sedemikian rupa untuk menjangkau fungsi kompleks sekalipun sesuai kebutuhan.

\section{E. Adobe Animate CC}

Adobe Animate $C c$ merupakan teknologi yang dikembangkan secara khusus oleh Perusahaan Adobe sebagai program Aplikasi Standar untuk alat pengembangan profesional animasi, web, maupun bitmap yang interaktif dan dinamis[6]. Adobe Animate CC mampu menghasilkan Multimedia Interaktif dengan beberapa format antara lain Apk, karena didalamnya terdapat tools tambahan berupa Adobe AIR for Android. Serta dapat terintegrasi dengan Teknologi pembuat vektor yang profesional seperti Adobe Ilustrator dengan 
tools Import sehingga Aplikasi yang dihasilkan lebih dapat memiliki Desain yang menarik dan solid.

\section{F. Mata Pelajaran Biologi}

Mata pelajaran Biologi merupakan merupakan salah satu bidang ilmu pengetahuan alam (Sains)[7] yang mempelajari makhluk hidupdari makhluk hidup unit struktural terkecil hingga terkompleks[2], memberikan pengalaman belajar terkait konsep dan proses sains dapat terlihat dalam Tuntutan Kurikulum 2013 yang mengharuskan beberapa Kompetensi Dasar dilaksanakan proses sains tersebut, berupa pengamatan, percobaan, dan simulasi[3]. Karena konsep-konsep sains banyak yang bersifat abstrak yang tidak bisa dipahami hanya dengan membaca saja.

\section{G. Sistem Pencernaan Makanan}

Materi sistem pencernaan makanan memuat konsep bersifat abstrak karena aktivitas nya didalam tubuh melibatkan organ dan enzim yang sulit diamati secara langsung, atau konsep dengan definisi yang membutuhkan pengalaman / pembuktian yang tidak bisa didapat hanya dengan membaca saja, sehingga pada materi ini selalu diadakan proses ilmiah seperti pengamatan, simulasi, dan praktikum / percobaan. Seperti Proses Pencernaan Makanan maupun Uji makanan untuk melihat kandungan makanan dan reaksi enzim.

\section{METODE PENELITIAN}

Penelitian ini disusun sebagai jenis penelitian dan Pengembangan atau Research and Development $(R \& D)$, yaitu Metode untuk menghasilkan suatu produk dan menguji kefektifan produk [8], dalam penelitian ini produk dalam pembelajaran. Penelitian $R \& D$ ini menggunakan Tahapan Penelitian Model Four-D (4D) oleh Thiagarajan, kombinasi dengan Model Pengembangan Multimedia Development Life Cycle $(M D L C)$ oleh Luther-Sutopo[4]. Lebih jelas dapat dilihat dalam gambar berikut :

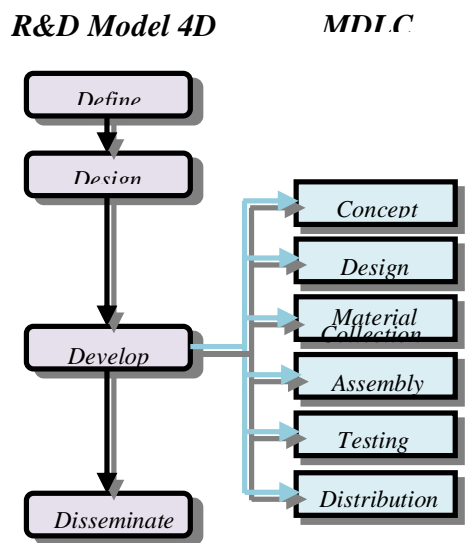

Gambar 1. Tahapan Penelitian dan Pengembangan

1. Define
Tahap ini dilakukan Studi Pendahuluan (Lapangan dan Literatur) untuk analisis latar belakang masalah dan mendefinisikan kebutuan.

2. Design

Tahap ini dilakukan desain secara umum bentuk media yang ditawarkan sebagai solusi.

3. Develop

Tahap ini dilakukakan pengembangan Media melalui tahapan MDLC Luther-Sutopo berikut:

a. Concept : Penentuan tujuan media, identifikasi pengguna, dan spesifikasi media.

b. Design : Perancangan arsitektur media secara rinci sesuai spesifikasi media. Berupa Struktur Navigasi dan Storyboard.

c. Material Collecting : Pengumpulan bahan yang diperlukan. Dapat dikerjakan secara liner dengan Assembly

d. Assembly: Pembuatan Media sesuai rancangan.

e. Testing : Pengujian keberfungsian struktur dan komponen media secara mandiri, disebut Alpha Test.

f. Distribution : Penyimpanan Produk dalam media penyimpanan, berformat tertentu.

\section{Disseminate}

Tahap ini dilakukakan penyebarluasan produk untuk diuji dan dianalisa lebih lanjut, diperbaiki, yang hasil akhirnya layak digunakan oleh para pengguna.

Produk diuji tingkat Validitas, Praktikalitas, dan Efektifitas menggunakan Angket Uji Coba Skala Likert dengan hasil dikonversi menjadi bentuk kuantitatif untuk dapat dianalisa dan diinterprestasikan, dengan tabel penentuan kriteria sebagai berikut :

Tabel 1. Kriteria Validitas Rumus Aiken's $V$

\begin{tabular}{|c|c|}
\hline Nilai V & Kategori Produk \\
\hline$<0,6$ & Tidak Valid \\
\hline$>=0,6$ & Valid \\
\hline
\end{tabular}

Tabel 2. Kriteria Praktikalitas Rumus Moment Kappa

\begin{tabular}{|c|c|}
\hline Nilai $\mathrm{K}$ & Kategori Produk \\
\hline $0,81-1,00$ & Sangat Praktis \\
\hline $0,61-0,80$ & Praktis \\
\hline $0,41-0,60$ & Cukup Praktis \\
\hline $0,21-0,40$ & Kurang Praktis \\
\hline$<0,21$ & Tidak Praktis \\
\hline
\end{tabular}

Tabel 3. Kriteria Efektifitas Rumus Presentase

\begin{tabular}{|c|c|}
\hline Nilai $\mathbf{P}(\%)$ & Kategori Produk \\
\hline $81-100$ & Sangat Efektif \\
\hline $61-80$ & Efektif \\
\hline $41-60$ & Cukup Efektif \\
\hline $21-40$ & Kurang Efektif \\
\hline $10-20$ & Tidak Efektif \\
\hline
\end{tabular}

\section{HASIL DAN PEMBAHASAN}




\section{Define}

Berdasarkan analisis masalah yang muncul di lokasi penelitian, didefinisikan bahwa dibutuhkan media berbasis teknologi untuk menunjang pembelajaran biologi pada materi yang memuat konsep abstrak dengan tuntutan kompetensi tinggi yang membutuhkan proses sains/pengalaman langsung seperti praktikum untuk menkonkret dan memenuhinya. Serta Media yang menarik, dapat diakses dalam 1 wujud di perangkat yang dominan dimiliki, mudah diakses kapan saja dan dimana saja.

\section{Design}

Berdasarkan Definisi kebutuhan, media akan dibuat mendekati Real Object memuat keinteraktifan, dengan tampilan dan fungsi yang menarik, serta berbasis pada perangkat yang dominan dimiliki pengguna di lokasi penelitian, yaitu Smartphone Android.

\section{Develop}

a. Concept

Media pembelajaran dalam penelitian ini dikembangkan untuk Guru Biologi dan Siswa kelas XI MIPA SMAN 1 Abung Semuli pada materi Sistem Pencernaan Makanan dengan kompetensi dasar 3.7 4.7.

Tujuan media dikembangkan agar Siswa tertarik dan aktif menggunakan media untuk belajar materi sistem pencernaan ditengah keterbatasan yang ada saat pembelajaran, sehingga Siswa dapat menkonkretkan konsep dan optimal memperoleh pengalaman belajar. Serta memudahkan Guru dalam membimbing Siswa memahami materi untuk mencapai tujuan pembelajaran dan memenuhi kompetensi yang diharapkan.

Media akan dikembangkan dalam Media interaktif model Virtual Laboratory, berisi simulasi praktikum di laboratorium nyata tentang Uji Makanan, dan disertai materi terkait, latihan, kompetensi Dasar, serta menu pendukung media. Media berwujud .Apk yang dapat diakses di perangkat Smartphone Android. Dikembangkan menggunakan Aplikasi Komputer Adobe Animate CC 2017, dengan pendukung Adobe Ilustrator 2019 serta Audacity. Layar beresolusi 1520 x 720 px dan tampilan landscape.

b. Design

1) Struktur Navigasi

Struktur Navigasi merupakan alur penampilan informasi pada media pembelajaran. Media akan dikembangkan menggunakan Model Campuran (Composite model). Model ini dipilih karena dapat memberikan keterkaitan informasi yang lebih baik.

Struktur Navigasi didesain untuk Halaman Intro, Home, Petunjuk, Pengembang, KD/Tujuan, Materi, Praktikum, dan Latihan. Secara lengkap dibawah ini :

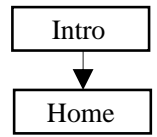

Gambar 2. Struktur Navigasi Intro

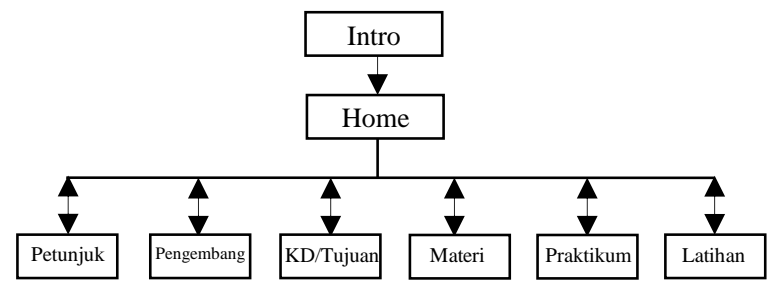

Gambar 3. Struktur Navigasi Home

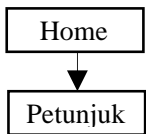

Gambar 4. Struktur Navigasi Petunjuk

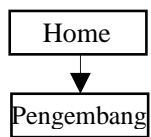

Gambar 5. Struktur Navigasi Pengembang

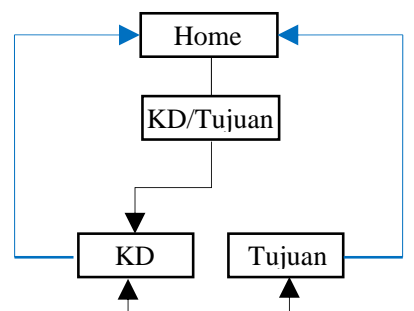

Gambar 6. Struktur Navigasi KD/Tujuan

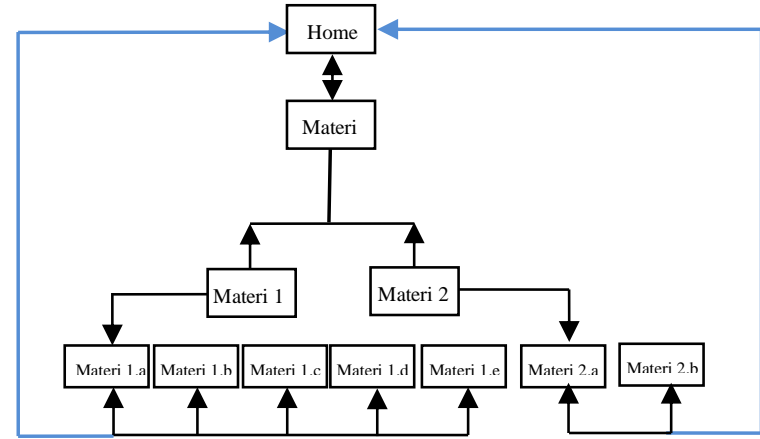

Gambar 7. Struktur Navigasi Materi

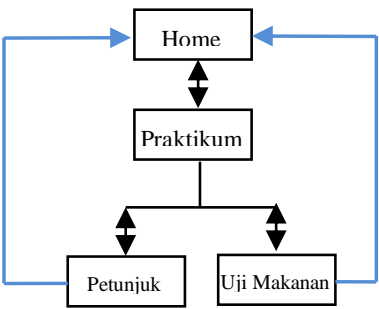

Gambar 8. Struktur Navigasi Praktikum

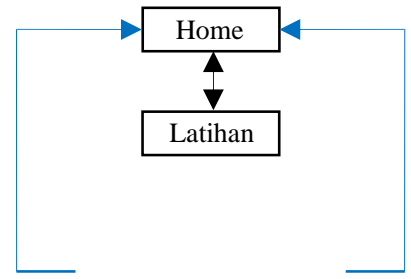




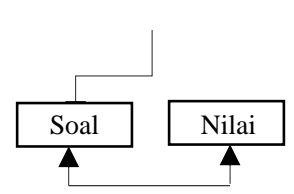

Gambar 9. Struktur Navigasi Latihan

\section{2) Storyboard}

Storyboard mencerminkan isi dari setiap Scene / Halaman, memuat visual / interface halaman, deskripsi dan elemen. Perancangan Soryboard mengacu pada Struktur navigasi. Berikut hasil perancangan Storyboard setiap Scene / Halaman Aplikasi yang akan dibuat:

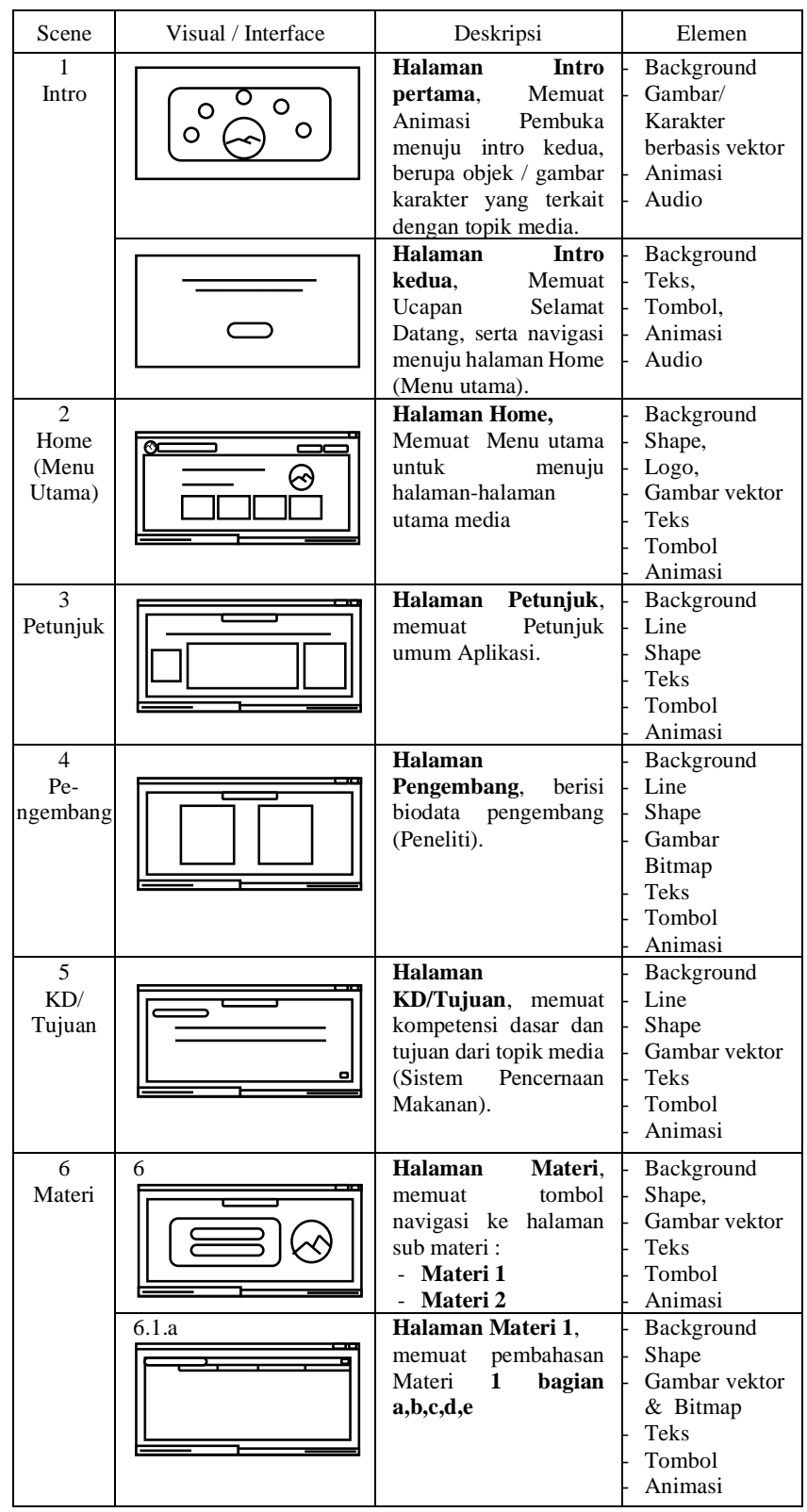

\section{c. Material Collecting}

Tahap ini dilakukan pengumpulan bahan sesuai kebutuhan media pembelajaran, berpedoman pada Storyboard. Bahan dibuat dengan Adobe Ilustrator 2019, maupun secara langsung di aplikasi utama Adobe Animate CC. Audio diolah dengan Audacity. Bahan murni dibuat sendiri maupun memodifikasi bahan dari internet seperti freepik.com, dll.

\section{d. Assembly}

Tahap ini dilakukan pembuatan media. Semua bahan Material Collecting ditransformasi menjadi halaman-halaman media pembelajaran yang sesuai konsep dan rancangan, dilakukan di dalam Aplikasi Utama Adobe Animate CC 2017. Berikut disajikan beberapa tangkapan layar proses pembuatan Media:

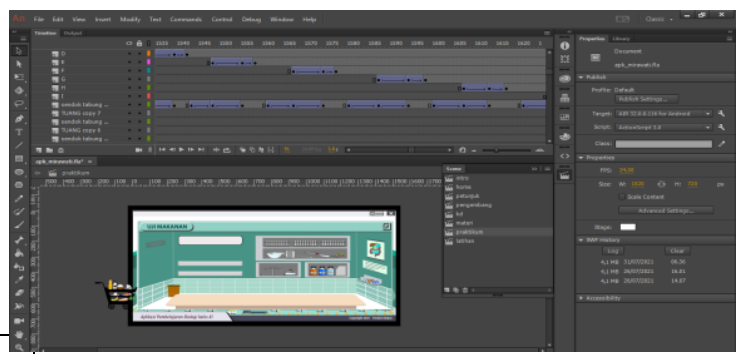

Gambar 10. Konfigurasi Komponen dan Halaman Media di Aplikasi Adobe Animate CC 2017 
Berikut Tampilan Media yang telah dihasilkan tahap Assembly :

a) Halaman Intro

Halaman ini merupakan tampilan pertama kali saat masuk aplikasi. Memuat animasi elemen, backsound, dan tombol ke halaman home.

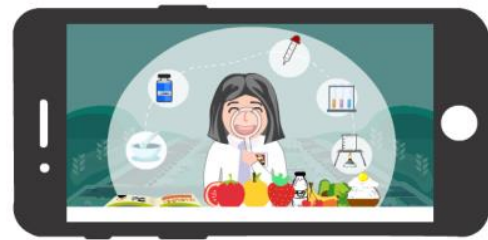

Gambar 12. Tampilan Intro Pertama

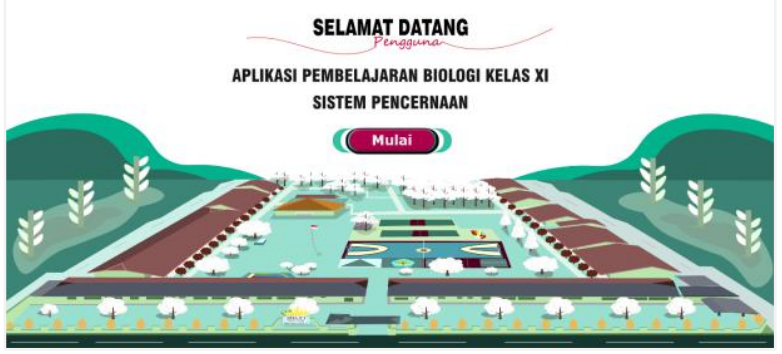

Gambar 13. Tampilan Intro Kedua

b) Halaman Home (Menu Utama)

Halaman ini adalah tempat menu utama Aplikasi berada, dapat mengakses dan diakses berbagai halaman menu utama.

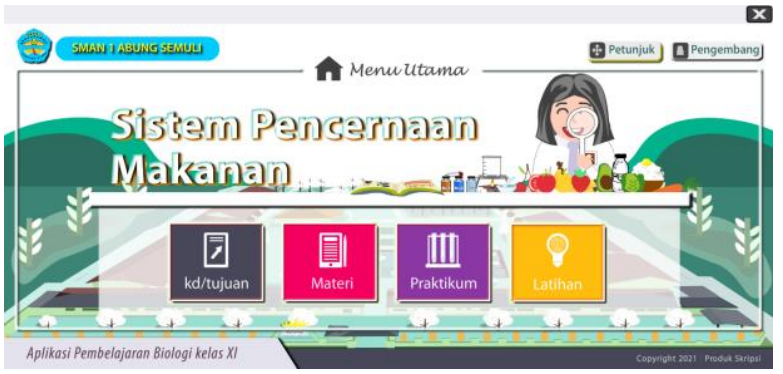

Gambar 14. Tampilan Halaman Home

c) Halaman Petunjuk

Halaman ini memuat petunjuk umum penggunaan aplikasi dan keterangan elemen didalamnya.

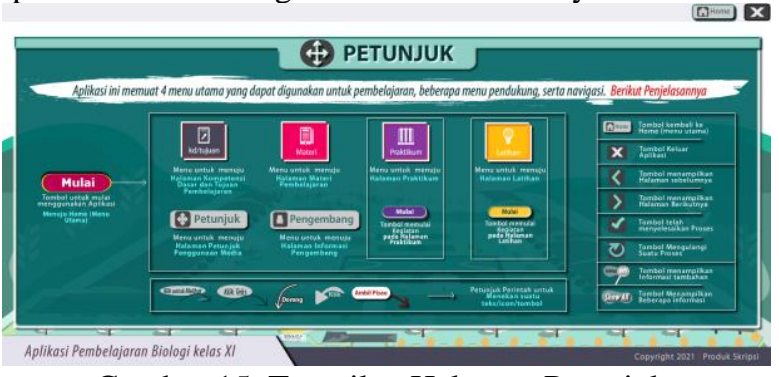

Gambar 15. Tampilan Halaman Petunjuk d) Halaman Pengembang

Halaman ini memuat Biodata Pengembang serta keterangan pengembangan.

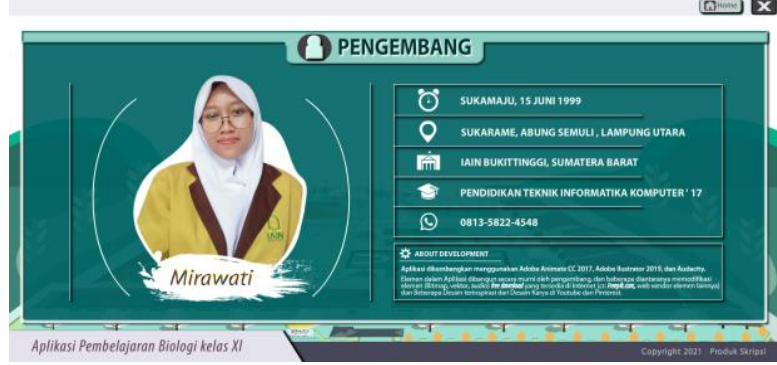

Gambar 16. Tampilan Halaman Pengembang

e) Halaman KD/Tujuan

Halaman ini memuat Kompetensi Dasar dan Tujuan pembelajaran Biologi pada materi Sistem Pencernaan Makanan kelas XI MIPA.

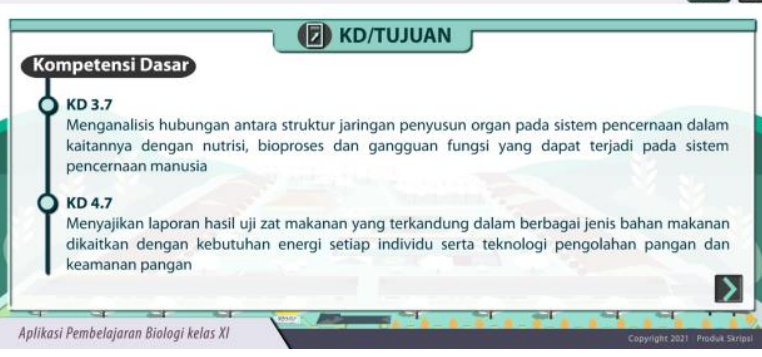

Gambar 17. Tampilan Halaman KD

f) Halaman Materi

Halaman ini merupakan halaman untuk mempelajari materi sistem pencernaan makanan, terdiri dari 2 sub pembahasan. Dalam setiap pembahasan memuat animasi, fungsi menarik serta interaktif, dan akses yang leluasa.

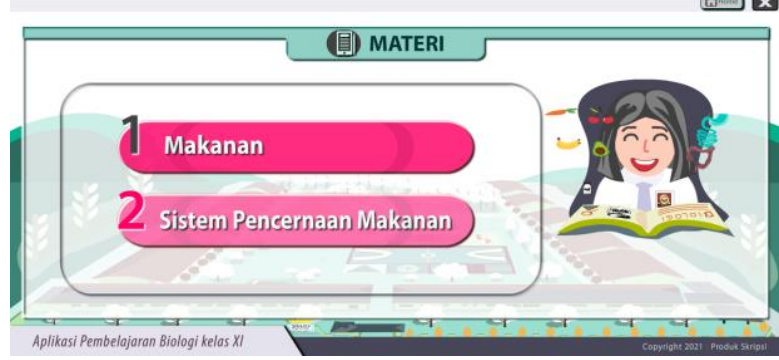

Gambar 18. Tampilan Halaman Awal Materi

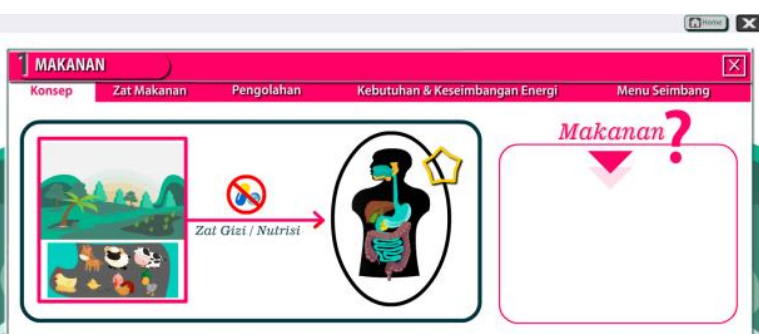

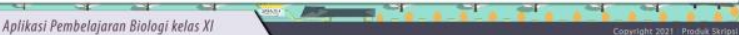

Gambar 19. Tampilan Halaman Materi 1 bagian a 


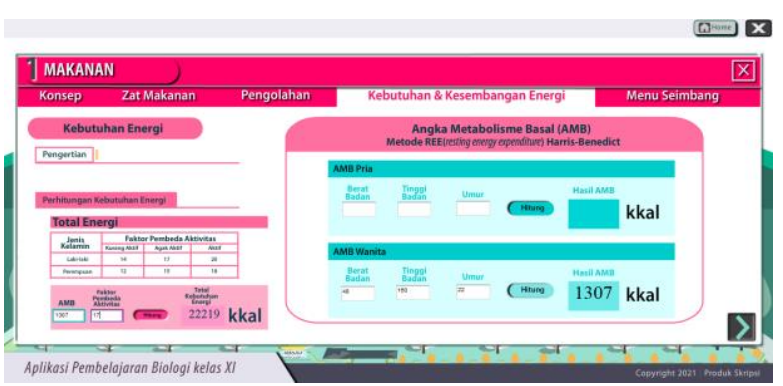

Gambar 20. Tampilan Halaman Materi 1 bagian d

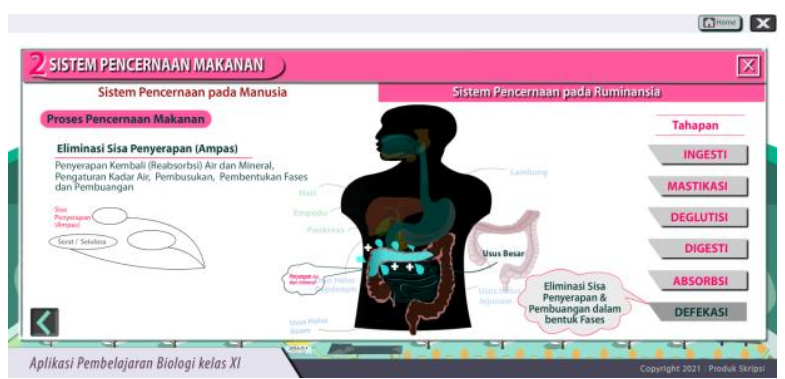

Gambar 21. Tampilan Halaman Materi 2 bagian a

g) Halaman Praktikum

Halaman ini berisi rangkaian simulasi kegiatan Uji Makanan yang diprogramkan memiliki animasi serta fungsi menarik dan interaktif dengan alur yang logis. Disertai dengan Petunjuk Praktikum.

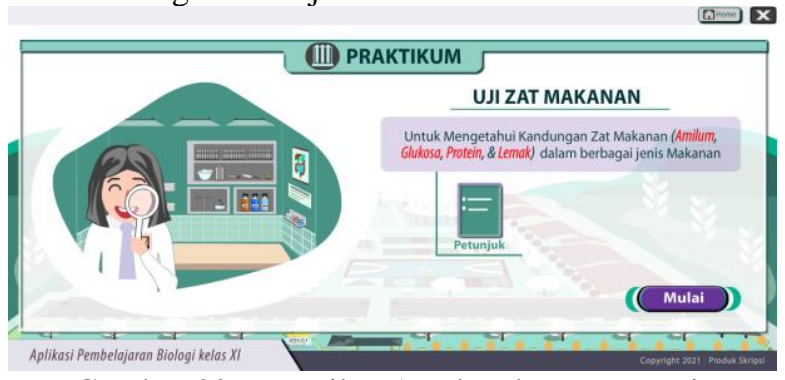

Gambar 22. Tampilan Awal Halaman Materi

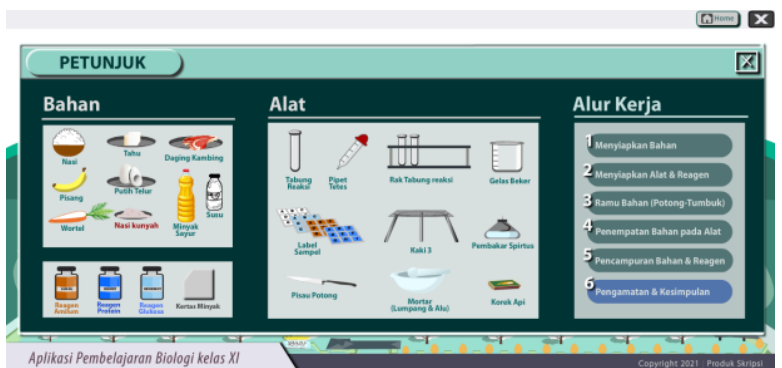

Gambar 23. Tampilan Halaman Petunjuk Praktikum

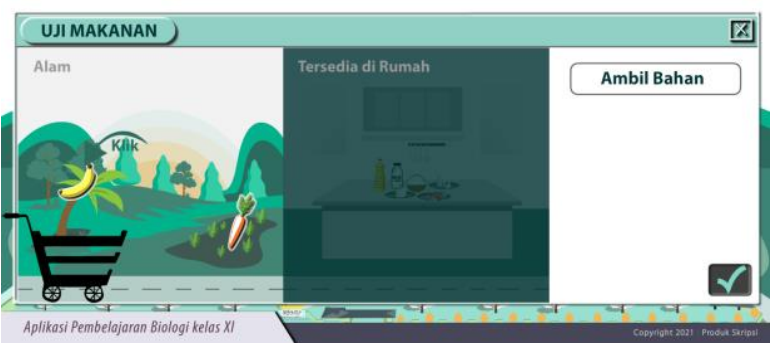

Gambar 24. Tampilan Halaman Kegiatan Praktikum

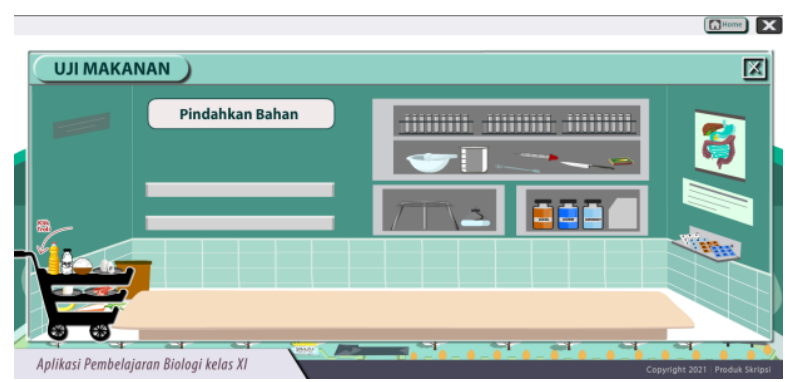

Gambar 25. Tampilan Halaman Kegiatan Praktikum

h) Halaman Praktikum

Halaman ini berisi kegiatan latihan setelah memahami materi dan praktikum. Diprogramkan memiliki animasi interaktif setiap pilihan jawaban dan umpan balik berupa salah/benar dan nilai.

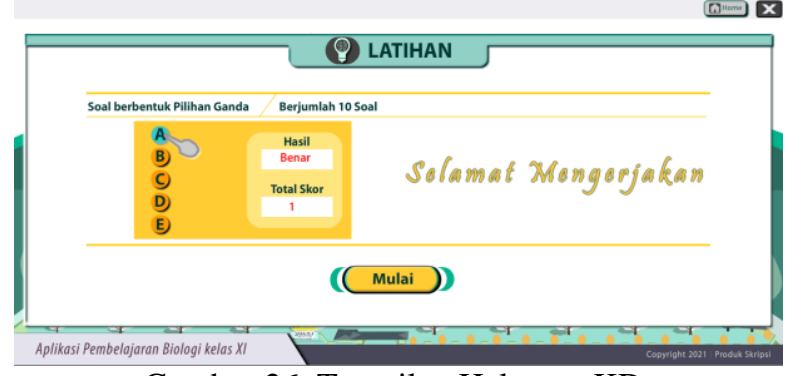

Gambar 26. Tampilan Halaman KD

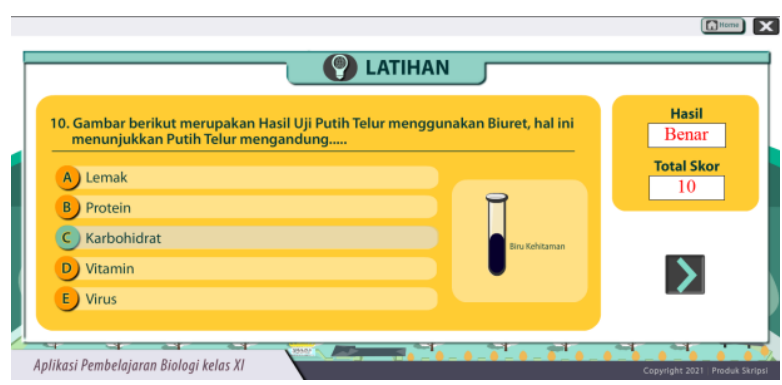

Gambar 27. Tampilan Halaman KD

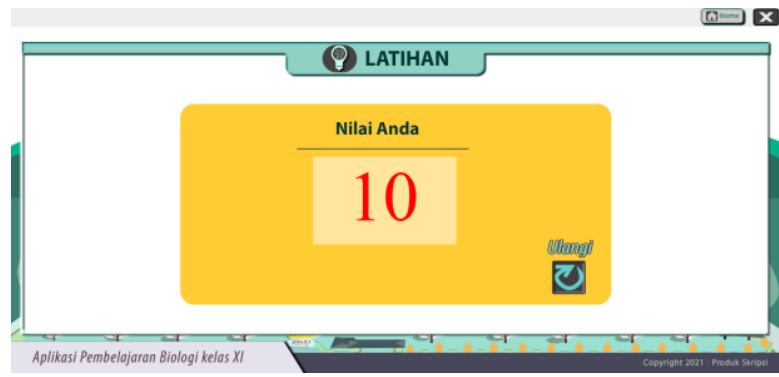

Gambar 28. Tampilan Halaman KD

\section{e. Testing}

Media yang telah selesai dibuat pada tahap Assembly diuji dengan Alpha Test. Hasil pengujian menunjukkan Elemen (Gambar, Tombol/Button, Animasi, Audio) tiap halaman Media sukses / tidak eror dan telah sesuai rancangan.

\section{f. Distribution}

Tahap ini dilakukan penyimpanan media menjadi Aplikasi berbasis Android (.Apk) melalui publish di Aplikasi Adobe Animate CC, berukuran $13 \mathrm{Mb}$. Lalu 
disimpan berbentuk link untuk disalurkan dan di instal pada perangkat Android. Spesifikasi perangkat akses berupa Smartphone Android minimal versi 6, RAM minimal 1GB, Memori Internal minimal tersedia 500 GB, Layar ideal 6,2 inch resolusi 1520x720 px.

\section{Disseminate}

Tahap ini dilakukan penyebarluasan produk kepada pihak yang terlibat yaitu kepada ahli dan Pengguna. Kepada Ahli Media dan Materi (Guru Mata Pelajaran Biologi) untuk mengetahui tingkat valid dan praktisnya media, dan beberapa Siswa Kelas XI MIPA di SMAN 1 Abung Semuli untuk mengetahui efektifitas media, dilakukan perbaikan sesuai saran. Kemudian dilakukan penyebaran final untuk dapat digunakan dalam pembelajaran kedepan.

Berikut disajikan Hasil Analisa Data Uji Coba Produk yang telah disebarluaskan, Data diambil dengan Angket tertutup Skala Likert.

Tabel 4. Hasil Analisa Validitas Produk

\begin{tabular}{|c|c|c|c|c|c|}
\hline \multirow[b]{2}{*}{ No } & \multirow[b]{2}{*}{ Validator } & \multicolumn{4}{|c|}{ Rata-rata Aspek Uji } \\
\hline & & Aspek Isi & \begin{tabular}{|c|} 
Aspek \\
Intruksional \\
Desain
\end{tabular} & $\begin{array}{c}\text { Aspek } \\
\text { Tampilan }\end{array}$ & $\begin{array}{c}\text { Aspek } \\
\text { Kebahasaan }\end{array}$ \\
\hline 1 & $\begin{array}{l}\text { Agus Nur Khomarudin, } \\
\text { S.Pd., M.Kom. }\end{array}$ & \multirow{3}{*}{0,83} & \multirow{3}{*}{0,85} & \multirow{3}{*}{0,85} & \multirow{3}{*}{0,88} \\
\hline 2 & $\begin{array}{l}\text { Dr. Liza Efriyanti, } \\
\text { S. Si., M. Kom }\end{array}$ & & & & \\
\hline 3 & Riri Okra, M.Kom & & & & \\
\hline \multicolumn{2}{|c|}{ Rata-rata Keseluruhan } & \multicolumn{4}{|c|}{0,85} \\
\hline \multicolumn{2}{|c|}{ Kriteria } & \multicolumn{4}{|c|}{ Valid } \\
\hline
\end{tabular}

Tabel 5. Hasil Analisa Praktikalitas Produk

\begin{tabular}{|c|c|c|c|c|}
\hline \multirow[b]{2}{*}{ No } & \multirow[b]{2}{*}{$\begin{array}{c}\text { Nama } \\
\text { Guru Bidang Studi }\end{array}$} & \multicolumn{3}{|c|}{ Rata-rata Aspek Uji } \\
\hline & & $\begin{array}{c}\text { Aspek } \\
\text { Didaktif }\end{array}$ & $\begin{array}{c}\text { Aspek } \\
\text { Kontruksi }\end{array}$ & $\begin{array}{l}\text { Aspek } \\
\text { Teknis }\end{array}$ \\
\hline 1 & Maria Budiani, S.Pd. & \multirow[b]{2}{*}{0.93} & \multirow[b]{2}{*}{0,92} & \multirow[b]{2}{*}{0,98} \\
\hline 2 & $\begin{array}{l}\text { Didik Purwantara, } \\
\text { S.Pd. }\end{array}$ & & & \\
\hline \multicolumn{2}{|c|}{ Rata-rata Keseluruhan } & \multicolumn{3}{|c|}{0,94} \\
\hline \multicolumn{2}{|c|}{ Kriteria } & \multicolumn{3}{|c|}{ Sangat Praktis } \\
\hline
\end{tabular}

Tabel 6. Hasil Analisa Efektifitas Produk

\begin{tabular}{|c|c|c|}
\hline \multirow{2}{*}{$\begin{array}{c}\text { Jumlah Siswa } \\
\text { Kelas XI MIPA }\end{array}$} & Aspek Media & $\begin{array}{c}\text { Aspek Materi dan } \\
\text { Pembelajaran }\end{array}$ \\
\cline { 2 - 3 } 14 & 95,36 & 93,57 \\
\hline Rata-rata Keseluruhan & \multicolumn{2}{|c|}{94,46} \\
\hline Kriteria & \multicolumn{2}{|c|}{ Sangat Efektif } \\
\hline
\end{tabular}

\section{KESIMPULAN}

Berdasarkan penelitian yang telah dilakukan, dapat diambil kesimpulan sebagai berikut :

1. Pengembangan yang telah dilakukan menggunakan Tahapan Model Pengembangan Four-D (4D) kombinasi MDLC, menghasilkan Aplikasi Virtual Laboratory berformat Apk. berukuran $13 \mathrm{MB}$ untuk mata pelajaran Biologi materi Sistem Pencernaan Makanan. Berisi Halaman Utama Intro, Home, Petunjuk, Pengembang, KD/Tujuan, Materi, Praktikum, dan Latihan.

2. Media Pembelajaran yang dihasilkan Valid, Praktis, dan Efektif digunakan Guru Biologi dan Siswa kelas XI MIPA dalam menunjang pembelajaran Biologi materi Sistem pencernaan Makanan. Dengan Nilai Validitas 0,85 dalam kriteria Valid Praktikalitas 0,94 dalam kriteria
Sangat Praktis. Nilai Efektifitas 94,46 dalam kriteria Sangat Efektif.

3. Aplikasi Virtual Laboratory menarik minat Siswa dan mampu membawa Siswa menkonkretkan konsep dan memperoleh pengalaman dengan atau tanpa bimbingan Guru, serta optimal belajar dalam keterbatasan pembelajaran, baik daring maupun tatap muka.

\section{DAFTAR PUSTAKA}

[1] I. N. T. Anindia Putra, K. S. Kartini, dan N. N. Widiyaningsih, "Implementasi Media Pembelajaran Interaktif Berbasis Mobile pada Materi Hidrokarbon," J. Pendidik. Kim. Indones., vol. 4, no. 2, hal. 43-52, 2020. http://dx.doi.org/10.23887/jpk.v4i2.28536

[2] T. A. J. Wulandari, A. M. Subuea, dan S. Siagian, "Pengembangan Media Pembelajaran Berbasis Multimedia Interaktif pada Mata Pelajaran Biologi," J. Teknol. Inf. Komun. dalam Pendidik., vol. 5, no. 1, hal. 75-86, 2018. https://doi.org/10.24114/jtikp.v5i1.12524

[3] W. C. Adi, Suratno, dan M. Iqbal, "Pengembangan Virtual Laboratory Sistem Ekskresi dalam Meningkatkan Motivasi Belajar Siswa SMA," J. Pendidik. Sains, vol. 4, no. 4, hal. 130-136, 2016. http://dx.doi.org/10.17977/jps.v4i4

[4] I. G. W. Sudhata dan I. M. Tegeh, Desain Multimedia Pembelajaran, I. Yogyakarta: Media Akademi, 2015.

[5] Daryanto, Media Pembelajaran (Perannya sangat Penting dalam Mencapai Tujuan Pembelajaran), II. Yogyakarta: Gava Media, 2018.

[6] Samsudin, M. D. Irawan, dan A. H. Harahap, "Mobile App Education Gangguan Pencernaan Manusia berbasis Multimedia Menggunakan Adobe Animate Cc," J. Teknol. Inf., vol. 3, no. 2, hal. 141-148, 2019. https://doi.org/10.36294/jurti.v3i2.1009

R. I. Wulandari, Harlita, dan Nurmiyati, "Pengembangan Media Pembelajaran Laboratorium Virtual berbasis Discovery Learning Materi Sistem Imun Kelas XI MIPA," Media Penelit. Pendidik., vol. 14, no. 1, hal. 61-70, 2020. https://doi.org/10.26877/mpp.v14i1.5640

[8] H. A. Musril, Jasmienti, dan M. Hurrahman, "Implementasi Teknologi Virtual Reality pada Media Pembelajaran Perakitan Komputer," JANAPATI, vol. 9, no. 1, hal. 83-95, 2020. https://doi.org/10.23887/janapati.v9i1.23215 